\title{
SUSTAINABLE DEVELOPMENT MODELING OF AGRITOURISM CLUSTERS
}

\author{
Kazlouski Vital ${ }^{1}$, Ganski Uladzimir ${ }^{2}$, Platonenka Alena ${ }^{3}$, Sabalenka Ina ${ }^{4}$ \\ ${ }^{1}$ Prof. Dr. habil. Yanka Kupala State University of Grodno. 22 E. Ažeški st., 230023 Grodno, Belarus. \\ Phone Number.+375336007789. E-mail:kazlouski_uv@grsu.by \\ ${ }^{2}$ Assoc. prof. Dr. Institute of Entrepreneurial Activity. 11 Serafimovič str. 220033 Minsk, Belarus. \\ Phone Number +375298122244. E-mail: ganski@tut.by \\ ${ }^{3}$ Assoc. prof. Dr. Yanka Kupala State University of Grodno. 22 E. Ažeški st., 230023 Grodno, Belarus. \\ Phone Number+375152485933. E-mail:platonenka_ai@grsu.by \\ 4 Asist. prof. Mgr. Belarusian National Technical University. 65 Niezaliežnasci ave. 220013 Minsk, Belarus. \\ Phone Number+375298760837. E-mail: sabalenka ia@bntu.by
}

Received 2209 2019; Accepted 06052020

\begin{abstract}
A systematic solution to the numerous environmental, social and economic problems of the development of agritourism cluster is not achievable without appropriate economic and mathematical models and tools for their support, which would make it possible to accurately predict the main indicators of the sustainable development of agritourism, identify the main factors of sustainable development, determine the degree of the effectiveness of certain management decisions. The purpose is to develop a structural model for sustainable development of agritourism, which makes it possible to predict the level of development of the tourism cluster and assess the impact of various management decisions impact on economic, environmental and social sustainability agrarian region. The article uses the method of modeling relationships between latent PLSPM variables as an analysis method, and the PLS analysis is intended for analyzing high-dimensional data in a poorly structured environment. The tool proposed in the article will allow you to determine the characteristics that have the greatest impact on the level of agritourism development. The described PLS analysis can be used to successfully solve the problems of sustainable development of the tourism cluster both at the level of regional government structures and at the level of agritourism business entities. Using modern theoretical and econometrical models authors made out recommendations as to develop agritourism for sustainable development of the tourism cluster on micro- and macrolevel.
\end{abstract}

Key Words: tourism, agritourism, cluster, sustainable development, mathematical modeling in economics.

JEL Codes: L84, Z3, Z32.

\section{Introduction}

The basic principles of the sustainable development concept in tourism was firstly defined by the World Tourism Organization (WTO) in 1988, although it has not received widespread practical application in tourism both in Europe and in other developed countries (Bramwell, 1993, p. 4). Destructive trends in the functioning of tourism clusters are still prevalent in individual countries and regions, reflecting the desire to quickly maximize profits to the detriment of sustainable development and strategic interests. Under the influence of almost uncontrolled anthropogenic impact, accelerated urbanization, investment and infrastructure construction, in many countries of the world, the natural and social environment of rural regions continue degrading and losing their unique recreational potential (Fong, 2017, p. 148).

Copyright (C) 2020. Published by Vytautas Magnus University. This is an open access article distributed under the terms of the Creative Commons Attribution Non-Commercial 4.0 (CC BY-NC 4.0) license, which permits unrestricted use, distribution, and reproduction in any medium provided the original author and source are credited. The material cannot be used for commercial purposes. 
A rational and balanced policy in the field of development of both tourism (agritourism in particular) can become one of the leading factors in successfully overcoming the crisis trends observed today in rural regions of many countries (Romao, 2017, p. 4-5). At the same time, in order to obtain a stable and lasting positive effect from the development of the agritourism cluster, strategic planning and management should be carried out based on the concept of sustainable development. The purpose of this concept is to increase the living standards of the local population due to economic growth from the development of agritourism cluster in the conditions of the unconditional preservation of socio-cultural values and environmental benefits of the local community (Buckley, 2012, p. 530). A systematic solution to the numerous environmental, social and economic problems of the development of agritourism cluster is not achievable without appropriate economic and mathematical models and tools for their support, which would make it possible to accurately predict the main indicators of the sustainable development of agritourism, identify the main factors of sustainable development, determine the degree of the effectiveness of certain management decisions (Kirstges, 2002).

In the context of global tourism crisis caused by the COVID-19 pandemic, it is agritourism clusters that have the greatest potential for market stability and development. Agritourism is mainly focused on domestic tourists, which should offset the closed of external borders and the lack of international tourist arrivals. Recreation in rural areas is associated with a minimum number of social contacts, which means that the risks of infection are minimal in comparison with most types of mass tourism, which should increase the level of confidence of tourists in their safety. Agritourism enterprises are usually small family-owned enterprises, which means that they can resume their activities faster and with less cost after a period of downtime in comparison with large tourist complexes, such as large seaside hotels.

All the above indicates a high degree of relevance of research of this kind and their relevance in current development conditions.

The researches of many scientists are devoted to the study of the sustainable development of tourism. Particularly questions about sustainable development in a tourism destination context study by J.B. Greenwood (2006); sustainable tourism indicators are investigated by Tanguay, Rajaonson and Therrien (2012); Ottenbacher, Schwebler, Metzler and Harrington (2015); research and reality of sustainable tourism consider by Buckley (2012), self-efficacy and sustainable rural tourism development study by Fong, Lo and Songan (2017); Evolutionary analysis of sustainable tourism analyzed by P. He, Y. He and Xu (2018); issues of interaction between the territory and sustainable tourism development is investigated by Romao, Guerreiro and Rodrigues (2017); regional aspect of the sustainable development model of tourism industry was studied by Aimagambetov, Bugubaeva, Bespayeva and Tashbaev (2017) etc. At the same time, researchers pay great attention to the theoretical development of the concept of tourism sustainability and its provision. Modeling of the prospects for sustainable development of agricultural territories study by Tymoshenko and KGolovach (2018); a dynamic model of sustainable tourism study by Tyrell and Johnston (2005); analyzing spatiotemporal patterns of tourism in Europe at high resolution with conventional and big data sources is investigated by Batista e Silva, Marin Herrera, Rosina, Ribeiro Barranco, Freire and Schiavina (2018) etc. However, the methods proposed by the authors only partially reflect the specifics of agricultural regions, and therefore the results obtained are not relevant to modeling the sustainable development of agritourism.

The purpose is to develop a structural model for sustainable development of agritourism, which makes it possible to predict the level of development of the agritourism cluster and assess the impact of various management decisions impact on economic, environmental and social sustainability of agrarian region. Object is the sustainable development of agritourism clusters. Subject is economic and mathematical modeling of agritourism development.

The basis of this study was the basic principles of the theory of system analysis, economic and mathematical modeling and their reflection in scientific works in the field of modeling sustainable development and development of tourism. As an analysis method, the article uses the method of modeling the relationships between implicit PLSPM variables. 
Methodology of Partial Least Squares Path Modeling (PLSPM) it began to be widely used in economic research in the 1970s. Partial Least Squares Path Modeling is a statistical data analysis methodology that exists at the intersection of Regression Models, Structural Equation Models, and Multiple Table Analysis methods. The PLSPM method is a tool for modeling relationships between implicit (latent) variables. The PLSPM technique is designed for studying high-dimensional data in a poorly structured environment. The conditions of the modeling problem in the PLSPM system can be represented as: $X$ is a block that consists of $p$ variables and $n$ observations. It can be represented as a matrix. The $X$ array can be divided into $j$ blocks. It is assumed that each such block is dependent with a latent variable, which is an abstract concept, perhaps even immeasurable and immaterial. All connections between variables in this problem are divided into two types: connections between latent variables and corresponding blocks, such connections form the external model, and connections of latent variables with each other, such connections form the internal model. A regional agritourism cluster is a good example of a complex system that can be analyzed using the PLSPM method. This is because sustainable agritourism is tourism in rural areas that meets the needs of external tourists without compromising the local rural population and nature, both now and in the future. The processes that take place in the agritourism cluster are a system of complex interaction of environmental, economic and social factors, the influence of which must be considered when developing a strategy for sustainable development of the agritourism cluster.

The PLSPM method is widely used in psychology (for evaluating such qualitative indicators as intelligence, commitment, and self-esteem), in sociology (social status), in economy (utility, level of economic development), in ecology (soil fertility), and in other sciences (Aimagambetov, 2017). PLSPM is freely available from the Comprehensive R Archive Network, better known as CRAN. Since version 0.4.0, PLSPM contains a set of features for handling non-metric data (discrete, ordinal, categorical, qualitative, etc.).

\section{Results}

The main problem of modeling sustainable tourism in many Eastern European regions is the frequent lack of enough statistical data. It is almost impossible to collect statistical indicators for a sufficiently long period that would affect not only the characteristics of economic development, but also would be related to the development of tourism in the region, the level of social comfort, and the costs of environmental protection (Tymošenko, 2018). Therefore, the initial task of the study was defined as the search for a region in the country for which the following conditions are met: there is an extensive database containing statistical data on different areas of the region's life (economic, social, environmental protection) for a long period of time (at least 20 years) (Ottenbacher, 2015); the region under study should have recreational resources that are quite common in Eastern Europe, where the development of sustainable tourism is an important task. Therefore, this is necessary to obtained simulation results can be used with certain assumptions to develop universal recommendations for the development of tourism.

As a result of the analysis of many regions of different countries, the region in the West of Belarus - the Grodno region - was chosen as the object of modeling. Firstly, there is a database for this region that contains statistical information on the economy, environment, employment, and many other areas of public life over a long period of time. Secondly, in terms of recreational resources, the Grodno region is like many other regions of Eastern Europe - its territory contains both flat territories, large rivers and large forests. Currently, the Grodno region is one of the most economically developed regions of Belarus. It is characterized by a well-developed financial sector, industry, tourism and agriculture. Due to the mild climate and fertile soils, the region is one of the first places in Belarus in terms of agricultural production. Grain, corn, various vegetables and other crops are grown in the fields of the Grodno region. Livestock, poultry and fishing are also well developed. In recent years, due to a sharp increase in demand, many farms in the region have shifted to the production of 
environmentally friendly products. Due to the nature and climate in the region traditional hiking, camping, cycling and hiking in the forests, excursions to cultural and natural heritage sites have become very popular. Thus, the Grodno region can be considered as one of the options for successful development: an economically developed region that has a high tourist attraction has preserved a rich cultural and natural potential, and where people engaged in agriculture have a high level of social comfort. Since this study uses statistical data on the development of the Grodno region since 1997, it can be considered as a variant of modeling the future development of sustainable agritourism.

The study identified four latent indicators that are related to quantitative (explicit) indicators of sustainability (Sharpley, 2000): the level of agritourism development (Agritourism sustainability), the level of social comfort (Social sustainability), the level of readiness of society to engage in environmental protection (Ecological sustainability), and the level of economic development (Economic sustainability).

Indicators of sustainable development of tourism in the city, proposed by J.B. Greenwood, are Travel Industry Employment (TIE), Travel Industry Payroll (TIP), Housing Values (HV), Local Tax Revenues from Tourism (LTR), Number of Subsidized Children (NSC), Human Services Expenditures (HSE), Unemployment Rate (UER), Environmental Protection Expenditures (EPE), Employment Ratio: Tourism to Total (ERT), Families in Poverty (FP), Public Safety Expenditures (PSE), Economic \& Physical Development Expenditures (EPD), Utility Revenues (UR), Utility Expenditures (UE), Total Water Use (TWU) and Average School Bus Mileage (ASB) (Greenwood, 2006, p. 72-76). It can be assumed that these same indicators can also be used to model sustainable tourism in an agricultural region / agritourism (Figure 1).

The external part of the model is the relationship of implicit (latent) variables $(\operatorname{Im} V)$ with explicit indicators, and the internal is the relationship of only latent variables. Thus, the analytical form of the internal part of the model is the following:

$$
\operatorname{Im} V_{\text {a.tour }}=\beta_{0}+\beta_{1} \operatorname{Im} V_{\text {Socials }}+\beta_{2} \operatorname{Im} V_{\text {Ecologics }}+\beta_{3} \operatorname{Im} V_{\text {Economics }}+\text { error }_{\text {a.tour }}
$$

where $\operatorname{Im} V_{\text {a.tour }}, \operatorname{Im} V_{\text {Socials, }} \operatorname{Im} V_{\text {Economic }}, \operatorname{Im} V_{\text {EcologicS }}$ are implicit (latent) variables, $\beta_{0}$ is a free term, $\beta_{1}$, $\beta_{2}, \beta_{3}$ are "path" coefficients, error a.tour is a residual term.

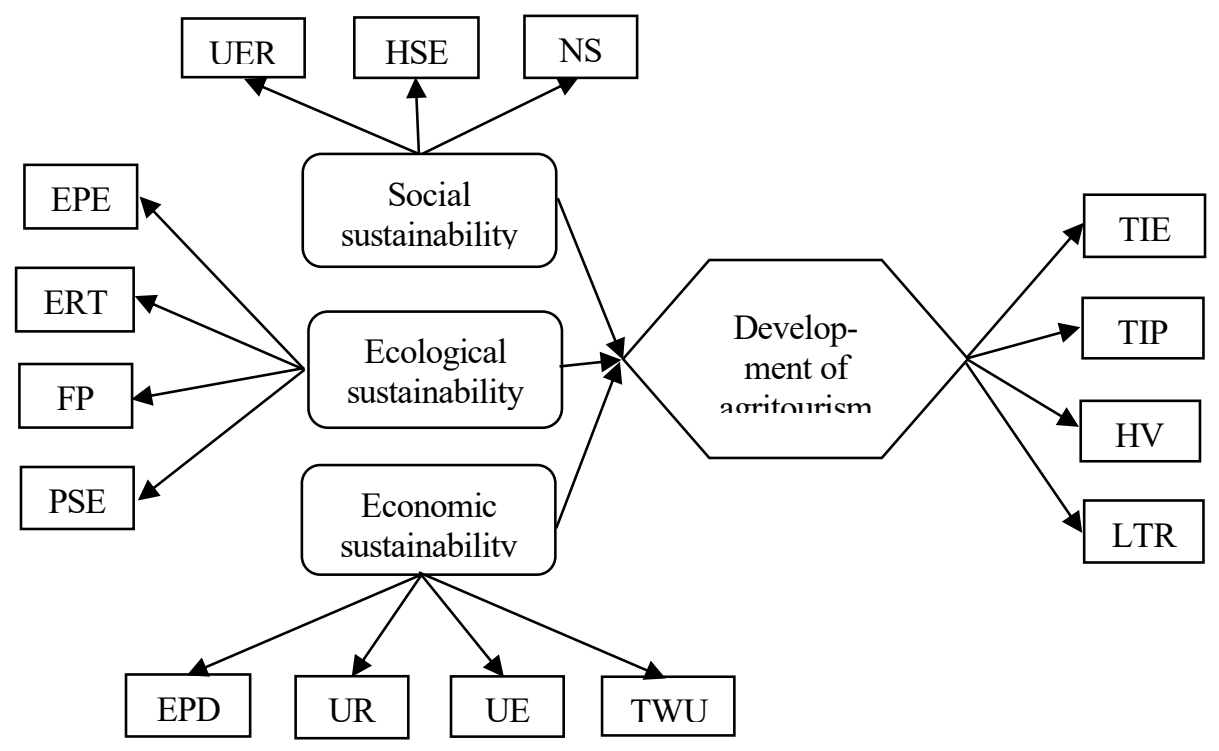

Figure 1. The initial model for the study of the sustainable development of agritourism cluster

Below is an analytical view of the external part of the model formed in the course of this study: 


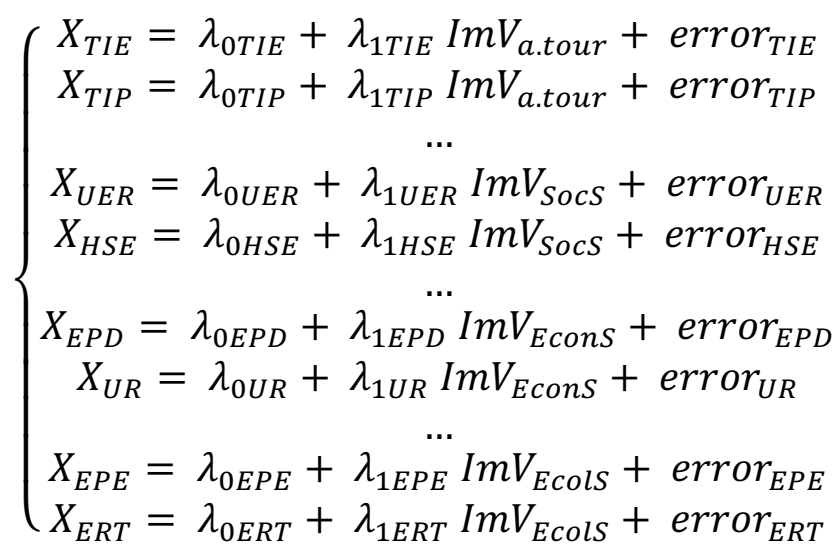

where $X_{T I E}, X_{T I P}, \ldots, X_{E R T}$ are explicit variables, $\lambda_{\text {OTIE }}, \lambda_{O T I P}, \ldots, \lambda_{O E R T}$ are free terms, $\lambda_{\text {ITIE }}, \lambda_{I T I P}, \ldots$, $\lambda_{I E R T}$ are load factors, error $_{T I E}$, error $_{T I P}, \ldots$, error $_{E R T}$ are residual terms.

In the method of modeling path coefficients using the least partial squares, we also introduce the concept of estimating a latent variable, which is a linear combination of the corresponding explicit variables $\left(Y_{j}\right)$ :

$$
\widehat{\operatorname{ImV}}_{j}=Y_{j}=\sum_{k} w_{j k} X_{j k}
$$

The system of equations shown below reflects estimates of implicit variables:

$$
\left\{\begin{array}{c}
\widehat{I m V}_{\text {a.tour }}=Y_{\text {a.tour }}=w_{T I E} X_{T I E}+w_{T I P} X_{T I P}+w_{V H} X_{V H}+w_{L R T} X_{L T R} \\
\widehat{I m V}_{\text {Socs }}=Y_{S o c S}=w_{U E R} X_{U E R}+w_{H S E} X_{H S E}+w_{N S C} X_{N S C} \\
\widehat{I m V}_{E c o l s}=Y_{E c o l s}=w_{E P E} X_{E P E}+w_{E R T} X_{E R T}+w_{F P} X_{F P}+w_{P S E} X_{P S E} \\
\widehat{I m V}_{E c o n s}=Y_{E c o n s}=w_{E P D} X_{E P D}+w_{U R} X_{U R}+w_{U E} X_{U E}+w_{T W U} X_{T W U}+w_{A S B} X_{A S B}
\end{array}\right.
$$

.4.)

whereby $w_{T I E}, w_{T I P}, \ldots, w_{T W U}$ we mean the external weights of the sustainable agritourism development model.

To pre-test the model, should perform a component analysis using the PLSDEPOT package. Component analysis confirms the correctness of the breakdown of variables by sector (Agritourism sustainability - Social sustainability - Ecological sustainability - Economic sustainability). Analysis of the model using the PLSPM package includes the following steps: checking internal consistency in blocks; checking the significance of variables in the external model; checking cross-correlations of block variables with latent variables of other blocks; checking the internal model; checking the quality of the model according to the model's data compliance index; optimizing the model.

The following criteria are used to check internal consistency in blocks in the PLSPM package: Cronbach's $\alpha_{K}$; the Dillon-Goldstein's $\rho_{D G}$; values of eigenvalues of the correlation matrix of explicit variables (He, 2018). The "Economic sustainability" and "Agritourism sustainability" blocks have good values of the coefficients $\alpha_{K}$ and $\rho_{D G}$. At the same time, the "Ecological sustainability" and "Social sustainability" blocks have poor internal consistency $\left(\alpha_{K}<0.7\right.$ and $\left.\rho_{D G}<0.7\right)$. In the Ecological sustainability block, the ERT and EPE variables have a negative correlation with the latent variable. The UER variable with negative correlation is also present in the "Social sustainability" block. This leads to internal inconsistency in blocks. After modifications of the FP, PSE, and UER variables, we get the consistency indicators of the external model. All three consistency criteria after modifications meet the necessary conditions $\left(\alpha_{K}>0.7, \rho_{D G}>0.7, \lambda_{1}>1, \lambda_{2}<1\right)$ (Tables 1-2). 
Table 1. Check the consistency of the model in the blocks

\begin{tabular}{|c|c|c|c|c|}
\hline Block & $\alpha_{K}$ & $\rho_{D G}$ & $\lambda_{1}$ & $\lambda_{2}$ \\
\hline \multicolumn{5}{|l|}{ Load factor } \\
\hline Economic sustainability & 0.88 & 0.91 & 3.41 & 0.72 \\
\hline Ecological sustainability & 0.00 & 0.00 & 2.98 & 0.73 \\
\hline Social sustainability & 0.00 & 0.58 & 2.37 & 0.38 \\
\hline Agritourism sustainability & 0.85 & 0.90 & 2.84 & 0.70 \\
\hline \multicolumn{5}{|l|}{ Load factor after modification } \\
\hline Economic sustainability & 0.88 & 0.91 & 3.41 & 0.72 \\
\hline Ecological sustainability & 0.88 & 0.94 & 1.78 & 0.22 \\
\hline Social sustainability & 0.85 & 0.93 & 1.74 & 0.26 \\
\hline Agritourism sustainability & 0.85 & 0.90 & 2.84 & 0.70 \\
\hline
\end{tabular}

Variables are considered significant if the load factor $\lambda_{1 \mathrm{j}}$ exceeds 0.7 . Based on the test results, the UR, UE, EPD, and HV variables should be excluded from the model. After checking the load factors $\lambda_{1 j}$, i.e. checking whether the explicit variables are connected to the latent variable of the corresponding block, it is necessary to check the cross-loads, i.e. to determine the strength of the connection between the explicit variables and the latent variables of other blocks.

This will avoid the presence of indicators-"traitors", i.e. such indicators, the strength of which is higher with the latent variable of another block than with the latent variable of the corresponding block.

Table 2. Load factors of variables in the external model

\begin{tabular}{|c|c|c|c|c|c|c|c|}
\hline \multirow[b]{2}{*}{ Blocks } & \multirow[b]{2}{*}{ Variable } & \multicolumn{2}{|c|}{$\begin{array}{l}\text { Load factors } \\
\text { of variables }\end{array}$} & \multicolumn{4}{|c|}{ Values of coefficients of external models } \\
\hline & & $\begin{array}{l}\text { Load } \\
\text { factor }\end{array}$ & $\begin{array}{c}\text { Load } \\
\text { factor after } \\
\text { modification }\end{array}$ & $\begin{array}{l}\text { External } \\
\text { weight }\end{array}$ & Load & $\begin{array}{c}\text { External } \\
\text { weight after } \\
\text { modification }\end{array}$ & $\begin{array}{l}\text { Load after } \\
\text { modification }\end{array}$ \\
\hline \multirow{2}{*}{$\begin{array}{c}\text { Economic } \\
\text { sustainability }\end{array}$} & TWU & 0.30 & 0.30 & 0.53 & 0.28 & 0.39 & 0.91 \\
\hline & ASB & 0.28 & 0.28 & -0.34 & 0.84 & 0.67 & 0.97 \\
\hline \multirow{4}{*}{$\begin{array}{c}\text { Ecological } \\
\text { sustainability }\end{array}$} & ERT & 0.45 & 0.45 & -0.90 & 0.86 & 0.33 & 0.93 \\
\hline & EPE & 0.80 & 0.80 & -0.45 & 0.45 & 0.30 & 0.81 \\
\hline & -FP & 0.86 & 0.86 & 0.36 & 0.31 & 0.29 & 0.90 \\
\hline & -PSE & -0.81 & 0.81 & 0.34 & 0.93 & 0.23 & 0.81 \\
\hline \multirow{3}{*}{$\begin{array}{c}\text { Social } \\
\text { sustainability }\end{array}$} & HSE & -0.93 & 0.93 & 0.30 & 0.81 & 0.34 & 0.90 \\
\hline & NSC & 0.90 & 0.90 & 0.29 & 0.90 & 0.42 & 0.91 \\
\hline & 1-UER & 0.81 & 0.81 & 0.23 & 0.81 & 0.36 & 0.86 \\
\hline \multirow{3}{*}{$\begin{array}{l}\text { Agritourism } \\
\text { sustainability }\end{array}$} & TIP & -0.86 & 0.86 & 0.34 & 0.90 & 0.41 & 0.99 \\
\hline & LTR & 0.89 & 0.89 & 0.42 & 0.91 & 0.22 & 0.77 \\
\hline & TIE & 0.90 & 0.90 & 0.36 & 0.86 & 0.44 & 0.97 \\
\hline
\end{tabular}

The binding strength of all explicit variables to the latent variables of their respective blocks is higher than with the latent variables of other blocks, i.e. all variables are "loyal" to their blocks.

Checking the quality of the internal model: the t-statistics criterion is performed for the "Ecological sustainability" and "Social sustainability" blocks $(\operatorname{Pr}(>|t|)<0.05)$, but not executed for the "Economic sustainability" block $(\operatorname{Pr}(>|t|)>0.05)$ (Table 3). 
Table 3. The values of the coefficients of cross-loading

\begin{tabular}{|l|c|c|c|c|c|}
\hline & Variable & $\begin{array}{c}\text { Economic } \\
\text { sustainability }\end{array}$ & $\begin{array}{c}\text { Ecological } \\
\text { sustainability }\end{array}$ & $\begin{array}{c}\text { Social } \\
\text { sustainability }\end{array}$ & $\begin{array}{c}\text { Agritourism } \\
\text { sustainability }\end{array}$ \\
\hline \multirow{2}{*}{$\begin{array}{l}\text { Economic } \\
\text { sustainability }\end{array}$} & TWU & 0.91 & -0.50 & -0.09 & -0.13 \\
\cline { 2 - 6 } $\begin{array}{l}\text { Ecological } \\
\text { sustainability }\end{array}$ & ASB & 0.97 & -0.54 & -0.09 & -0.23 \\
\cline { 2 - 6 } & ERT & -0.49 & 0.93 & 0.58 & 0.81 \\
\cline { 2 - 6 } & EPE & -0.33 & 0.81 & 0.58 & 0.73 \\
\cline { 2 - 6 } & -FP & -0.63 & 0.90 & 0.65 & 0.72 \\
\hline \multirow{3}{*}{$\begin{array}{l}\text { Social } \text { sustainability } \\
\text { Agritourism }\end{array}$} & HSE & -0.48 & 0.81 & 0.64 & 0.56 \\
\cline { 2 - 6 } & NSC & -0.04 & 0.58 & 0.90 & 0.69 \\
\cline { 2 - 6 } sustainability & 1-UER & -0.11 & 0.75 & 0.91 & 0.84 \\
\cline { 2 - 6 } & TIP & -0.24 & 0.52 & 0.86 & 0.72 \\
\cline { 2 - 6 } & LTR & 0.09 & 0.43 & 0.68 & 0.99 \\
\hline
\end{tabular}

At the optimization stage, this block can be excluded from the model. The $\mathrm{R}^{2}$ indicator for the "Agritourism sustainability" target block is more than $80 \%$. The share of reproducible variability characterizes the share of block variability that is reproduced by the latent variable of this block. For all blocks, this figure is much higher than $50 \%$, which positively characterizes the model under study. The AVE index (the percentage of extracted variance) for all blocks exceeds $50 \%$, so the internal model is also considered satisfactory by this criterion.

Calculation of a single coefficient of quality of the model's compliance with data - GoF (Goodness-of-Fit). The coefficient characterizes the quality of the model, both internal and external, and serves as an indicator of the reliability of the predictive model (Batista e Silva, 2018). The predictive reliability of the model is considered high if the GoF coefficient exceeds the value of $70 \%$. For the model studied in this paper, the GoF coefficient is $82 \%$.

Model optimization: all criteria that characterize the quality of the model are met, except for the t-statistics criterion for the "Economic sustainability" block in the internal model. Let's exclude the "Economic sustainability" block from the system and perform all the verification steps for the updated model. The first step is to check internal consistency in blocks. The second stage is checking the significance of variables in the external model. The third stage is to check cross-correlations of block variables with latent variables of other blocks. The fourth stage is the validation of the internal model. The fifth stage is to check the quality of the model based on the model's data compliance index (Tyrell, 2005). The GoF coefficient in the new model is $86 \%$. In this case, the internal model of the system will have the following form:

$$
\operatorname{Im} V_{\text {a.tour }}=0.55 \operatorname{Im}_{\text {Socs }}+0.43 \operatorname{Im}_{\text {Ecols }}+\text { error }_{\text {a.tour }}
$$

Such characteristics as Environmental and Social sustainability with a power of influence of 0.43 and 0.55 , respectively, have a very significant impact on the level of agritourism development. During the study, it was found that the impact of economic sustainability on the development of agritourism in Grodno region is very small. Most likely, this fact is explained by the specifics of a particular research area. At the same time, the following equations were obtained for estimating implicit variables:

$$
\left\{\begin{array}{c}
\widehat{I m V}_{\text {a.tour }}=0.42 X_{T I E}+0.39 X_{T I P}+0.27 X_{L T R} \\
\widehat{I m V}_{\text {Socs }}=0.37\left(1-X_{U E R}\right)+0.34 X_{H S E}+0.42 X_{N S C} \\
\overline{I m V}_{E c o l s}=0.3 X_{E P E}+0.33 X_{E R T}-0.29 X_{F P}-0.23 X_{P S E}
\end{array}\right.
$$


Two characteristics have a significant impact on the level of agritourism development in the region: the level of social comfort and the level of readiness of society to engage in environmental protection with a power of influence of 0.55 and 0.43 , respectively. In addition, the study revealed a rather weak influence of the level of economic development on the development of agritourism. Perhaps this is due to the specifics of the analyzed territory. However, the lack of significant dependence of agritourism on the economic factor gives some hope if you extrapolate the results of the simulation to a specific region: sustainable agritourism development is possible in both an economically developed region and a developing one. The results can be shown graphically (Figure 2).

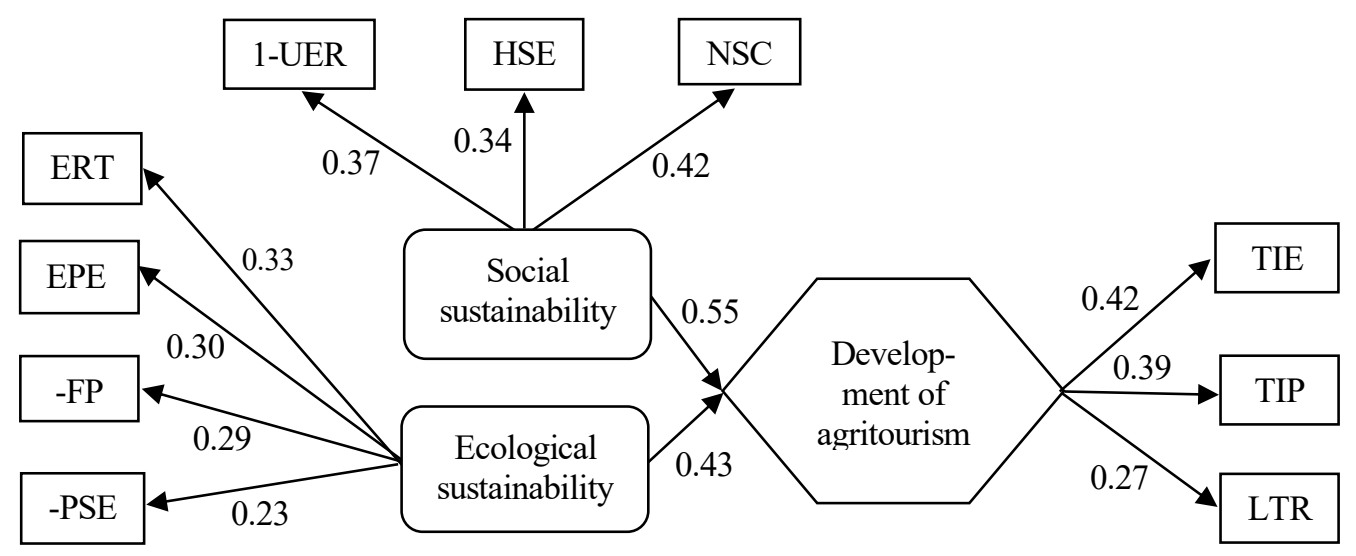

\section{Figure 2. The final model of sustainable development of agritourism cluster}

According to the results obtained, the level of social comfort can be estimated by three factors: the level of employment (the share of people with permanent jobs in the total number of economically active population); the amount of public spending on health care and other social services; the average monthly number of children receiving subsidies for treatment. The level of readiness of society to protect the environment can be estimated by four factors: the amount of public spending on environmental protection; the share of jobs in the tourism industry in the total number of jobs; the number of families with an income below the subsistence level (negative dependence); the amount of public spending on public safety (negative dependence).

The state and problems of sustainable development of agritourism cluster in the Grodno region are today quite complex and ambiguous. Some of them are systemic or even institutional in nature, which cannot be solved without a large-scale reform of the entire country. Factors that hinder the sustainable development of agritourism in the Grodno region include: lack of full-fledged private land ownership in Belarus; the relative small number of farmers in the conditions of domination of inefficient large state owned agricultural enterprises; people can freely use numerous forests, rivers and lakes for tourist and recreational purposes (they are mostly not privately owned in Belarus); a large number of potential tourists have family and friendly ties in rural areas, where they can get agritourism services for free; many citizens have their own small country houses for recreation; as well as some socio-demographic factors. Here are listed mainly those factors that distinguish the situation in the Grodno region, and which are unique.

More universal problems of sustainable development of agritourism clusters is: too weak promotion of the region as a tourist attractive region for rural recreation (this situation can be changed by the relevant advertising campaigns of local and regional authorities); lack of experience in the field of agritourism, administrative and legal barriers (most of these problems can be solved by working with various organizations that support rural development, such as rural tourism associations, local action groups, and others); financial limits (in this case, it is possible to attract funding for the development of agritourism from external sources, including funds from rural development programs, for example, within the framework of EU assistance, national and foreign grants, assistance programs, etc.). 
In what direction will the changes in the development of agritourism go? It can be assumed that a large share of the market will have specialized agritourism enterprises with a proposal intended for a specific segment of tourists, and a smaller share will be typical agricultural farms. The quality of basic services (accommodation, meals, etc.) will be constantly improved while maintaining their originality and authenticity. The fashion for a "return to nature" already leads to the fact that a great advantage of farms are dishes prepared based on their own organic products. We can assume that interest in such offers will continue to grow in the future.

\section{Conclusions}

A significant component of economic growth for rural areas and regions with significant tourist and recreational potential is the development of agritourism cluster. In such a situation, the application of economic and mathematical models of sustainable development is the development of wellthought-out, justified and balanced decisions in the field of economic, regional and tourism policies.

The tool proposed in the article will allow you to determine the characteristics that have the greatest impact on the level of agritourism development. The described PLSPM analysis can be used to successfully solve the problems of sustainable development of the tourism cluster both at the level of regional government structures and at the level of agritourism business entities. At the same time, it is necessary to understand that strategic planning and monitoring of results are impossible without truthful comprehensive statistical data and their scientific analysis, which is still so lacking.

Based on the final model, you can calculate latent indexes for each year and create a simulator for predicting future values. When making decisions that affect the level of social comfort and the level of ecology in the region, they have a direct impact on the development of agritourism. Used methodology can be used for any region of the national economy measurement, considering universal approach.

The presented results can be useful in university teaching process of disciplines related to economic and mathematical methods and models, regional planning and development, sustainable tourism for bachelors and master's programs in the field of economics, management and territorial development. The results may also be useful to different studies: they can be useful in conducting research on modeling of sustainable development, modeling the development of tourism in general and agritourism, sustainable development of rural areas, etc. The presented methodology can be applied not only to agritourism studies, but also to most other types of tourism and recreation. It is also possible to use the results obtained in practice of public policy and administration: the results can be applied in practice in tourism management and marketing, in territorial planning to justify complex management decisions and local investment projects.

\section{References}

Aimagambetov, E.B., Bugubaeva, R., Bespayeva, R., Tashbaev, N. (2017) Model of sustainable development of tourism industry in Kazakhstan (regional perspective) // Viešoji politika ir administravimas. Vol. 16(2). 179-197. - http://doi:10.13165/VPA-17-16-2-02 [2019 11 28]

Batista e Silva, F., Marín Herrera, M.A., Rosina, K., Ribeiro Barranco, R., Freire, S., Schiavina, M. (2018). Analysing spatiotemporal patterns of tourism in Europe at highresolution with conventional and big data sources. // Tourism Management. Vol. 68. 101-115. - http://doi.org/10.1016/j.tourman.2018.02.020 [2019 1128$]$

Bramwell, B. Lane, B. (1993). Sustainable tourism: An evolving global approach. // Journal of Sustainable Tourism. Vol. 1. 1-5. - http://doi: 10.1080/09669582.2017.1251689 [2019 11 28]

Buckley, R. (2012). Sustainable tourism: Research and reality. // Annals of Tourism Research. Vol. 39. 528-546. - http://doi:10.1016/j.annals.2012.02.003 [2019 1128 
Fong, S.F., Lo, M.C., Songan, P. (2017). Self-efficacy and sustainable rural tourism development: Local communities' perspectives from Kuching, Sarawak. // Asia Pacific Journal of Tourism Research. Vol. 22. 147-159. - http://doi:10.1080/10941665.2016.1208668 [2019 11 28]

Greenwood, J.B. (2006). Sustainable development in a tourism destination context: a Plimsoll model of sustainability in Tyrell Country, North Carolina. PhD diss., North Carolina State University. -https://repository.lib.ncsu.edu/bitstream/handle/1840.16/41/pdf?sequence=1\&isAllowed=y [2019 11 28]

He, P., He, Y., Xu, F. (2018). Evolutionary analysis of sustainable tourism. // Annals of Tourism Research. Vol. 69. 76-89. - http://doi:10.1016/j.annals.2018.02.002 [2019 11 28]

Kirstges, T. (2002). Basic questions of "sustainable tourism": does ecological and socially acceptable tourism have a chance? // Current Issues in Tourism. Vol. 5. 173-192. http://doi:10.1080/13683500208667917 [2019 11 28]

Ottenbacher, M.C., Schwebler, S., Metzler, D., Harrington, R.J. (2015). Sustainability Criteria for Tourism Attractions: A Case Study of Germany. // International Journal of Social Ecology and Sustainable Development. Vol. 6. 20-39. - http://doi:10.4018/ijsesd.2015040102 [2019 11 28]

Romao, J., Guerreiro, J., Rodrigues, P.M.M. (2017). Territory and sustainable tourism development: a space-time analysis on European regions. // Region. Vol. 4. 1-17. - http://doi:10.18335/region.v4i3.142 [2019 1128$]$

Sharpley, R. (2000). Tourism and sustainable development: exploring the theoretical divide. // Journal of Sustainable Tourism. Vol. 8. 1-19. - http://doi.org/10.1080/09669580008667346 [2019 11 28]

Tymošenko, M., Golovach, K. (2018). Modeling of the prospects for sustainable development of agricultural territories by the bayesian networks. // Management Theory and Studies for Rural Business and Infrastructure Development. Vol. 40. 263-273. - http://doi:10.15544/mts.2018.2 [2019 11 28]

Tyrell, T.J. Johnston, R.J. (2005). A dynamic model of sustainable tourism. // Journal of Travel Research. Vol. 44. 124-134. - http://doi:10.1177/0047287505278987 [2019 11 28] 